\title{
エアジェットルームにおけるよこ系の張力変動
}

$\begin{array}{cllll}\text { 豊田中央研究所 } & \text { 吉 } & \text { 田 } & \text { 一 } & \text { 德 } \\ " \text { " } & \text { 川 } & \text { 端 } & & \text { 行 (会員) } \\ \text { " } & \text { 長 谷川 } & \text { 準 } & \text { 三 ( " ) }\end{array}$

\section{Tension Fluctuation of Weft Yarn in Air Jet Loom}

\author{
K. Yoshida, S. Kawabata, \\ and J. Hasegawa \\ Toyota Central Res. \& Develop. Labs., Inc., \\ Nagakute, Aichi-gun, Aichi
}

\begin{abstract}
Yarn tension fluctuation occuring in the end stage of weft insertion were investigated experimentally and analytically.

Measurements of yarn tension in the middle position between mainnozzle and gripper were presented. These results were compared with the theoretical results and discussed in point of yarn breakage.

Upper limits of loom speed derived from relationships between yarn tensile strength and the peak tension were estimated.

(Received 30 May, 1987)

\section{摘 要}

目的 エアジェットルームに抽て，よこ糸として紡績系を用いた際のよこ入れ終了時に発生する張力上昇に関し， 噴射条件, 特に糸のゆるみとの関連性を中心にその発生状況を明らかにする. 又, 各種の紡績系について, その張力ピーク と破断強度分布をもとに，糸切れからみたよこ入れ率の上限についても検討する.

成果 エアプール方式において，メインノズルとグリッパーの中間にロードセルを設置して張力変動を測定したそ の結果，局部的なゆるみを伴うこともなく系が正常に飛走する場合には，自由噴射終了時 $t_{p}$ 及びグリッパ閉時 $t_{0}$ の 2 度に わたって張力がパルス状に急上昇し， $t_{p}$ 時に生ずる張力の伝播速度は，静止した糸を加振して求めた伝播速度に比べ $30 \%$ ほど低いことが分かった。この原因は，正常飛走する場合でも系が $2 \%$ 程度ゆるみを伴うためと考えられる. 又リレ一噴 射の特徴である系中央に局部的なゆるみがある場合についても，張力变動の発生状況を実験により明らかにした。

以上の実験結果並びに糸の強度分布からみて，よこ入れ率の上限は，よこ入れ時間をクランク角度で $140^{\circ} に$ 設定して製

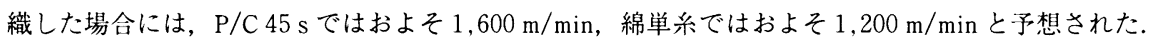

(昭和62年 5 月 3 日受理)

\section{1.まえがき}

空気噴流を推進力としてよこ入れを行い布を織る エアジェットルームは最近になって急速に高速化が 進み，よこ入れ率（おさ幅 $\times$ 回転数）が 1,800 $\mathrm{m} / \mathrm{min}$ を越える機種も開発されるに至っている. しかしながらこのような高速運転を実現するには強 度が高く，かつ，むらの少ない系を用いる必要があ り，通常の紡績糸を用いた場合には，系切れによる
停台が起きやすく，安定した製織は難しいように 思われる.この糸切れの原因の 1 つとして, よこ 入れ終了段階で発生する張力上昇があり，この張力 上昇は高速で飛走していたよこ糸が，その上流端で 瞬時に制動を受けることによって生じる，系が完全 な弾性体であるならば，この現象は一次元的な波動 現象と考えることができ，比較的容易に取扱うこと ができる1 31. しかし現実には，系は圧縮に耐えら れないばかりでなく，一般にその伸長特性は非線形 
であり，さらに後述するように，よこ系飛走の際に は少なからず波打っている. 従ってよこ入れ終了時 の波動伝播状況並びに張力波形は, 通常の弾性体の 場合に比べきわめて複雑となるものと予想される.

本報告ではこうしたよこ入れ終了時に生ずる張力 上昇に関し，噴射条件，特に系のゆるみとの関連性 を中心にその発生状況を明らかにする，又，各種の 紡績系について，その張力ピーク值と破断強度分布 をもとに，系切れからみたよこ入れ率の上限につい ても検討する。

\section{2. 記 号}

本報で用いる主な記号を以下に示す。

$a$ : 張力の伝播速度 $(=\sqrt{E / \rho})$

$E \quad:$ 弾性率 $(=d T / d \varepsilon)$

$E_{s}$ : 伸長特性より求めた平均弾性数

$L \quad$ : 下流端までの距離

$N$ : 織機回転数

$P_{m}:$ メンノズル供給压力

$P_{s}:$ サブノズル供給圧力

$t$ : 時間

$T$ : 張力（引っ張り方向を正にとる）

$T_{p}:$ 張力のピーク值

$v \quad:$ 糸の速度

$V:$ 系の先端速度

$x$ : 距離（下流方向を正にとる)

$\rho:$ 系の線密度

$\varepsilon ：$ 線ひずみ（伸び方向を正にとる）

\section{3. 張力変動の測定}

\section{1 実験装置の構成及び測定方法}

本研究で取扱う張力はきわめて小さく, 又, 高周 波の成分を含んでいる。 それゆえその測定には細心 の注意が必要であるが，この測定を実機で行おうと すると機械の振動や検出器の設置, さらにはその取 扱いといった問題があり, 高精度の測定はなかなか 難しい，そこで本研究では実機のかわりに，よこ入 れ装置一式を静止した台上に組立てたよこ入れ試験 機を使用した。試験機の構成を図 1 に示す。試験機 では，よこ系の貯留方式としていわゆるエアプール 方式を用いており，搬送方式としてサブノズルを併 用したエアガイド方式を用いている.

この試験機の動作は以下のとおりである。まず, 系巻き(1)より連続的にフィードローラ(2)によって一 定速度で糸を引出し，この糸をエアプール装置(3に 送り込み, 空気流によってU字状に浮遊させた状態

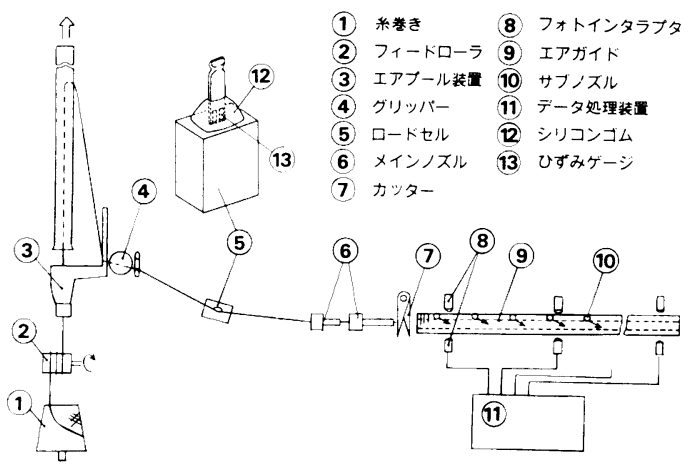

図 1 よこ入れ試験機の構成

でいったん貯留する，そして糸の噴射開始に先立っ てメインノズル6に高圧空気を送り込み，メイン， ズル内の圧力がほぼ定常值に達した段階でそれまで 系を把持していたグリッパー(4)を開放し，系をエア ガイド(9)の飛走通路内に向けて空気とともに噴射す る. 飛走通路の側壁には $50 \mathrm{~mm}$ ピッチでサブノズ ル10が設置してあり，バルブを次々と切替えること によってサブノズルをリレー噴射し，エアガイドの 端へと系を運んでゆく。

図 2 には，本実験で用いる糸の噴射夕イミング並 びにバルブの切り替えタイミングを示す．織機の回 転をおさ打ち時を起点とした角度で表示すると，グ

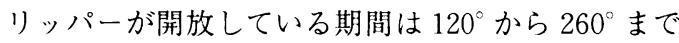
の $140^{\circ}$ の期間である. 又, サブノズル用バルブは, サブノズル 4 本に対し 1 個の割で計18個配置されて おり，系先端に空気流が噴射されるよう，それぞれ が糸の飛走にあわせて順次開弁する.

グリッパーを閉じて系を把持した後，カッタ(7)に よって系を切断する．実機では，この段階でよこ糸 がエアガイドのスリットから抜け出て，おさにより 布の中へと打込まれるが，試験機ではそのかわりに サブノズルを $340^{\circ} \sim 60^{\circ}$ の期間一斉に噴射して，飛 走通路内に残っている系を通路外へと排出する.

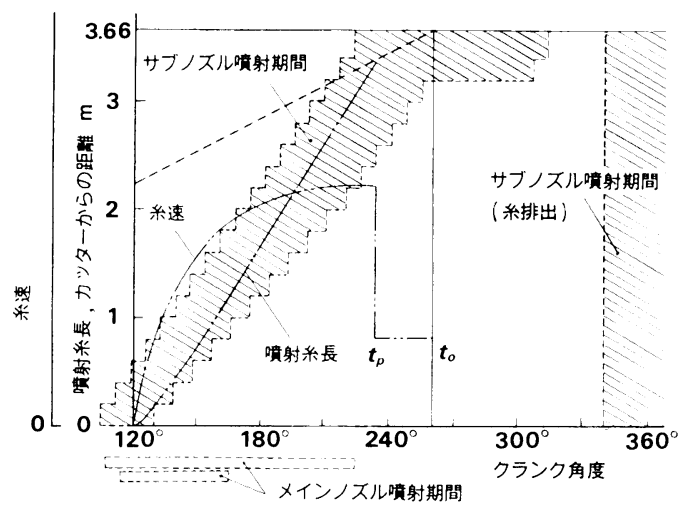

図 2 噴射夕イミング 
よこ入れの際の系の速度は, 図 2 にその特徵を示 すように噴射開始とともに急速に上昇し，エアプー ル内の浮遊糸量がゼロとなった段階で瞬時に低下 し，その後グリッパーが閉じるまでの期間はフィー ドローラの周速に一致する．本報では前者の浮遊糸 量がゼロとなるまでの期間を自由噴射期間，後者の フィードローラ周速にその速度が一致する期間を拘 束噴射期間と呼び，グリッパー開放を起点とした 各々の噴射の終了時刻を $t_{p}, t_{0}$ と記す。

次に糸の張力ならびに速度の測定方法について述 ベる．系張力は図 1 に示すようにメインノズルとグ リッパーの間にロードセル(5)を配置し，その検出部 で糸を四のようにわずかに屈曲させ，そのときの張 力の分力より算出した。このロードセルは焼き入れ 鋼板製で，先端部に系の接触位置を規制するための 溝を加工し，支持部近くに，ひずみゲージを貼りつ けてある．検出部を片持ち梁とみなして曲げ振動の 固有振動数を計算した結果によれば, 一次の振動数 は $4 \mathrm{kHz}$ 程度である。ひずみの出力の増幅には応答 周波数が $2 \mathrm{kHz} \quad(-1 \mathrm{~dB})$ の動ひずみ計（新興通信 製，6001-F 型）を使用した。

系の速度は光学的な方法を利用して測定した。 そ の方法はエアガイドの飛走通路を狭んで多数のフォ トインタラプタ (8)を配置し, 系の先端が通過する時 刻を次々に計測し，設置間隔と系通過時間差とから 速度を求めるものである. 本実験には36個のフォト インタラプタを設置し，速度の算出にはマイクロコ ンピュータを組込んだデー夕処理装置(11)使用し た．系の先端速度はよこ入れのたびにわずかではあ るが変化し，自由噴射終了時刻 $t_{p} に は$ 変動係数で 約 $2 \%$ の変動がみられる.今回の実験では100回の 平均値でその速度を代表させた。

\section{2 張力上昇パターン}

図 3 に張力波形の測定例を示す。この例はよこ系 にポリエステル綿混紡系（P/C） $45 \mathrm{~s}$ を用い，運転 回転数を $300 \mathrm{rpm}$ ，噴射長を $3.66 \mathrm{~m}$ (よこ入れ率 $1,098 \mathrm{~m} / \mathrm{min}$ ) に設定し, 又, 回転数の割にサブノ ズルへの供給圧力 $P_{s}$ を高めに設定し，飛走中の系 に局部的なゆるみが生じないようにしてょこ入れし た場合の代表例である。 なお，この時の $t_{0}$ は 77.8 $\mathrm{ms}$ であり， $t_{p}$ は $t_{0}$ の $80 \%$ となるよう設定した。

張力は図に示すように噴射開始前後でわずかに増 加し，その後いったん低下したのち，自由噴射終了 時刻 $t_{p}$ でパルス状に急上昇する．噴射中期で張力 が低下するのは, 系速の增加に伴って系と空気流と の相対速度が減少し推進力が低下するためで, 又,

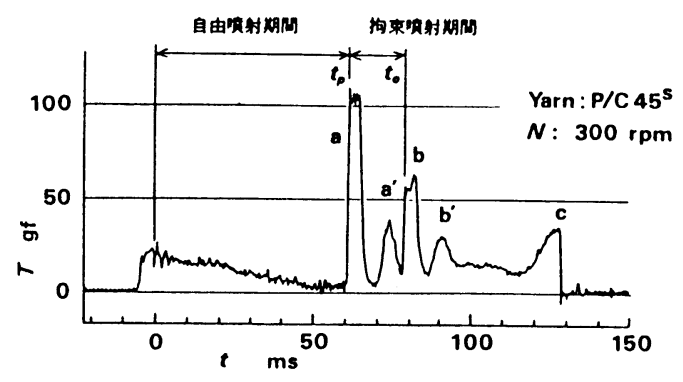

図 3 張力波形の測定例

$t_{p}$ の際のパルス状の張力上昇は，飛走中の糸が瞬時 にフィードローラの周速まで減速することにより生 ずる.このパルス状の張力変化はその発生機構から いって非定常的な波動現象とみなすことができる. ここで以下のような仮定，すなわち，

(1) 糸の動きは一次元的な運動とみなしうる,

(2) 周囲の空気及びエアガイドとの摩擦は無視で きる,

（3）系は完全な弾性体とする,

(4) 張力伝播速度に比べ系速は著しく小さく，無 視できる，

のもとで，その運動を表す基礎方程式を導けば，次 式で示すよく知られた一次元の波動方程式が得られ る.

$$
\frac{\partial^{2} T}{\partial t^{2}}=a^{2} \frac{\partial^{2} T}{\partial x^{2}}
$$

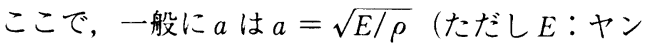
グ率， $\rho$ : 密度）で与えられるが, 紡績系の場合そ の断面積が必ずしも明確でないので，本報では，E $=($ 張力 $) /($ 線ひずみ $), \rho$ : 線密度を用いることに する.

飛走していた系の上流端が瞬時に減速すると，波 動理論によれば，上流端では張力が急上昇し, 張力 波となって伝播速度 aで下流に向って伝播してい く.この波が下流端に達すると波は反射し，上流へ と戻ってくる.その結果，このときの上流端におけ る糸張力の波形は, 下流端までの距離 $L$ を張力波 が往復する時間，すなわち， $2 L / a$ をパルス幅とし た矩形波となる. 又, 張力のピーク値 $T_{p}$ は, 減速 直前の張力をゼロとし，減速前後の速度差を $\Delta v$ と すると，以下のようになる1!.

$$
T_{p}=a \rho \Delta v=\sqrt{E \rho} \Delta v
$$

さて図 3 において， $t_{p}$ の際に生ずる張力上昇の波 形 $\mathrm{a}$ をると，その波形には，わずかにロードセル の過渡振動と思われる高周波振動が重畳している が，これを除けばおおむね矩形波状となっている. 
図からパルス幅 $\Delta t$ を読取ると約 $4 \mathrm{~ms}$ で，ちなみに このパルス幅から拉およその伝播速度 $a$ を計算する と, $L$ を張力計より $t_{p}$ 時の系先端までの長さ $3.9 \mathrm{~m}$ として,

$$
a=2 L / \Delta t=7.8 / 0.004=1,950(\mathrm{~m} / \mathrm{s})
$$

を得る.

又, 張力ピーク值は約 $110 \mathrm{gf}$ であり, $\Delta v=49.2$ $\mathrm{m} / \mathrm{s}, \rho=1.34 \times 10^{-6} \mathrm{kgfs}^{2} / \mathrm{m}^{2}$ として, (2)式より 伝播速度 $a$ を求めると, $a=1,670 \mathrm{~m} / \mathrm{s}$ を得る.

このように, 伝播速度の值は, 算出方法によって やや異なっており，厳密に現象を説明するには，(1) 式で示す波動方程式では不充分と言える。これは紡 績系という材料の持つ非線形性並びに系の飛走状態 に起因すると思われ，その理由については後述する。

この $t_{p}$ の際の張力上昇の後に, a' で示す $30 \mathrm{gf}$ ほ どの張力上昇がみられる.この山は $t_{p}$ の際の張力 上昇のいわば余波ともいうべき山で，その発生機構 としては， $t_{p}$ の際の張力上昇の後に生じた圧縮力に よりいったん弛緩した糸が, その後, 空気力により よこ入れ万向に再び移動し, その時上流端で再度制 動を受けることによって生じると考えられる.

次にグリッパが閉じると，系は速度ゼロまで急制 動を受け，その際 a と同様な原因により立上がりの 鋭い張力上昇 $\mathrm{b}$ が生じ, 又, その後 $\mathrm{a}^{\prime}$ と同様の原 因により b'が生じる. b' 以後張力はしばらく一定 值を保つが，これはサブノズルによる空気力による ものである. 次いで系はカッ夕により切断され，そ の際に糸が刃先の移動によって引っ張られ， c で示 す山が生じる. c の直後に張力がわずかではあるが 負の値となる．張力が負となることは測定法からい って起こりえないので，これはロードセルの過渡振 動による䛊差とみなすことができる.

以上，糸が局部的なゆるみを伴うことなく正常な 状態で飛走する場合について張力波形の特徵を述べ た.このような場合においては，その波形は比較的 単純であり, 張力のピーク値の問題を除いては特 に現象的には注目すべき点は無いようである。この 張力ピーク值は(2)式で示すように伝播速度と相互に 関連し，工業的な面からこれを定量的に明確にして おくことが必要である. 本研究の対象である紡績系 の場合，こうした張力伝播に関する報告例がみあた らない. そこでまず基礎的に紡績系の場合の張力伝 播状況を調べた。

\section{4. 伝播速度の測定}

(1)式における伝播速度 $a$ は一般に音速と呼ばれ，
液体・気体・金属など代表的な材料については資料 が整っている. 又, 完全な弾性体とみなせるような 材料の場合, 伝播速度 $a$ は, 前述のように, $\sqrt{E / \rho}$ で与えられるので， $E$ と $\rho$ を個別に測定して計算に より求めることができる.しかし紡績系の場合には, 系内部の繊維間の摩擦や繊維の粘弾性的な特性によ ク，その伸長特性はひずみ速度に依存することは周 知であり, 通常の静的引張り試験により得られる $E$ を音速の計算に用いることは誤差が大きいように思 われる，そこで伝播速度を，Eを用いた計算によら ず，伝播速度の定義に従って，直接的な方法により 測定することを試みた。

図 4 に, 伝播速度測定のための装置を示す. 糸は, その一端が加振器(3)に固定されており, 受振器(4)で 直角に曲げられたのち, 水平に張りわたされ, 他端 が受振器(6)固定される.この状態で, 加振器(3に よって系にわずかな張力パルスを印加し，そのとき に2 個の受振器において検知される張力の過渡波形 を計測し，その波形から伝播遅れ時間を求め伝播速 度を計算する。

本実験では, 加振器(3)として, 罒中に示すような プランジャタイプのソレノイドを製作し使用した. 図 5 に, ソレノイドへの印加電圧とうず電流式の非 接触変位計を用いて測定したプランジャ変位 $s$ の波 形を示す.プランジャのストロークは $1.2 \mathrm{~mm}$ で, プランジャが動き始めてからこの距離を移動するに 要する時間は $1.8 \mathrm{~ms}$ である. プランジャが移動を 終えた時点で, プランジャには衝突振動が発生する が, その振幅は $0.1 \mathrm{~mm}$ 程度とストロークに比べわ ずかで, その持続時間も短い.なお, コイルには $50 \mathrm{~ms}$ の間通電し, 通電を停止の後は, プランジャ はばね力により原位置に復帰する。

張力波の受振器としては, 前述の張力測定に用い たものと同形状のロードセルを使用した。このロー

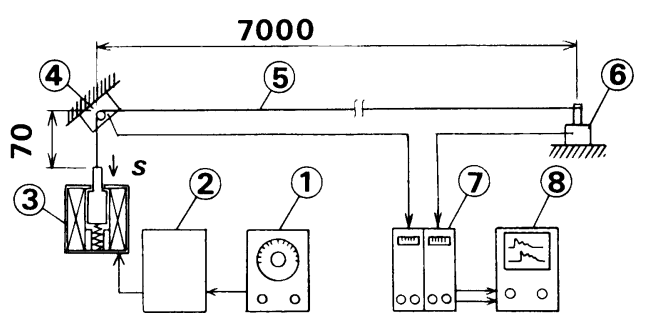
(1) パルス発生器
(5) 試験系
(2) ドライバ
(3) 加振器
(6) 受振器
(4) 受振器
(7) 動ひずみ計
(8) オシロスコープ

図 4 伝播速度の測定装置 

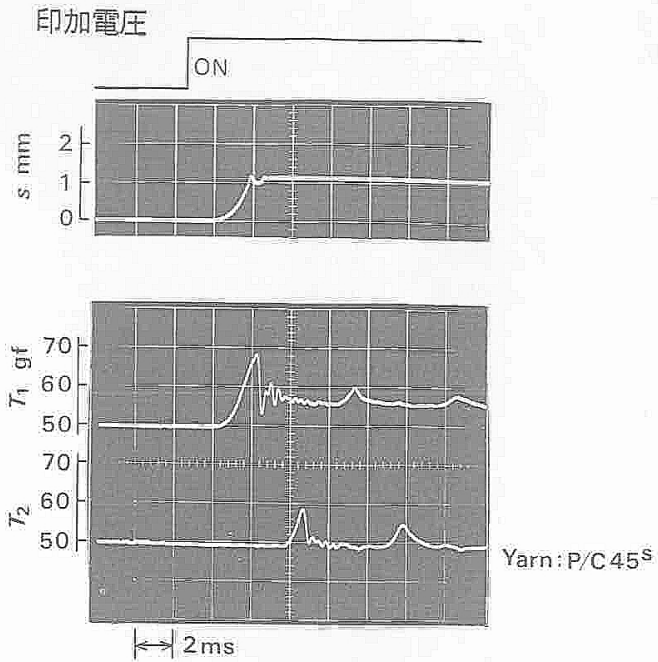

图 5 プランジャ変位 $s$ し張力の波形

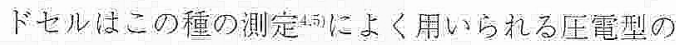
検出器に比べ応答性加必要しも良人ないが，しかし 陚料を長くすれば，伝播遲机時聞肪大きくなって， 応答性が低いことに上る測定精度の問題は解消可能 である、以上のよう辛観点から，本実験では陚料の 長岂老 $7 \mathrm{~m}$ 上比較的長く設定した。测定心際しては， 糸の伸びを安定化さ接目的で，50 gf 程度の初張

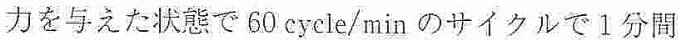
励振したの方張为泌形老オシロスコープに描か世, 只の波形を写真摄影した。

図 5 に張力波形の観測例を储せて示す。T缓

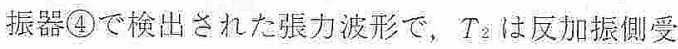
振器(6)の波形である。 景に科って直線的に增加し，プランジャが停正した のちに、ステップ状に低下手。ここで訾力が低下

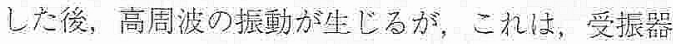
の過渡振動度びタ゚ランジャの衝突振動に起圈すると

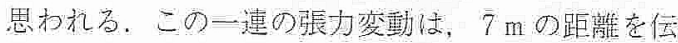

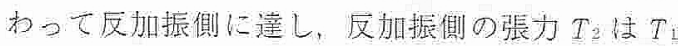

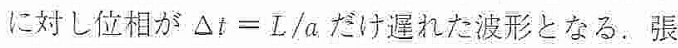

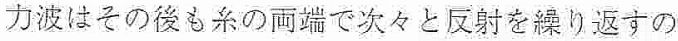

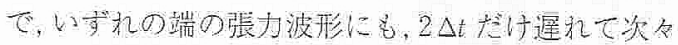
とピータが現われ，そして次第に隇袁していく。こ こで，プランジャが吸张机系端が図4の下方向に 移動した際に加振劃張力 T、は図 5 の例では 6 gf 程 度 Tgに比へ平均均に高くなるガ，これは受振器(4)

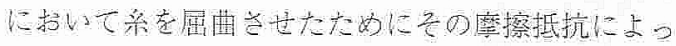

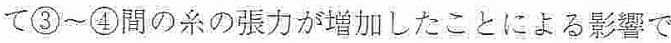
あり，反加振側ではこの上うな現䘚は起こっていな い. 前述のようにプランジャ変位は全長に教し， $0.02 \%$ 以下と特かであるので，プランジャが変
位した(4)ょり(6)の区問の掁力変化よ設定掁力に比心

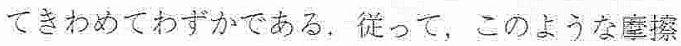

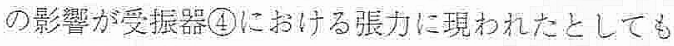

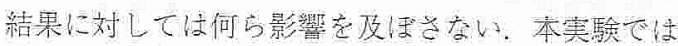
摩掽によ当誤差の少ない反加振側で測った静的張力 在設定張力と呼心ことに市る.

以上の上う擗張力波形の性質から，2つの受振器 の伝播僬れ時閏の加和に，各多の受振器での㖘力 波形の周期を㜔取ることによっても伝播邆度を求め ることがで姜，先に述へた伝播遮れるり求めた伝 插速度と, 張力波形の周期加ら求めた伝播速度は，

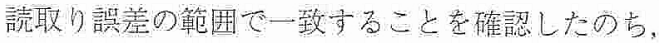
各種緔績系について伝播速度を測定した。

図 6 に5 種類の系について設定張力豙变更し，传

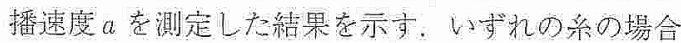
も設定張力の增加とともに伝播速度加上昇していく

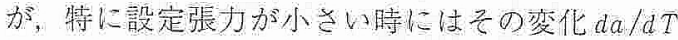
は大きくなる，設定張力に対する線密度 $\rho の$ 变化は 小さいので,このような伝播這度の非線形性巣性

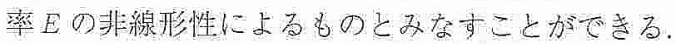

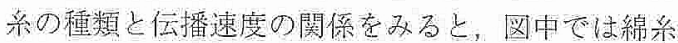

(C) $80 / 2 \mathrm{~s}$ が最も佉播速度が高く，設定張力が 50 gf において 4,000 m/sに達している. 又, P/C $45 \mathrm{~s}$

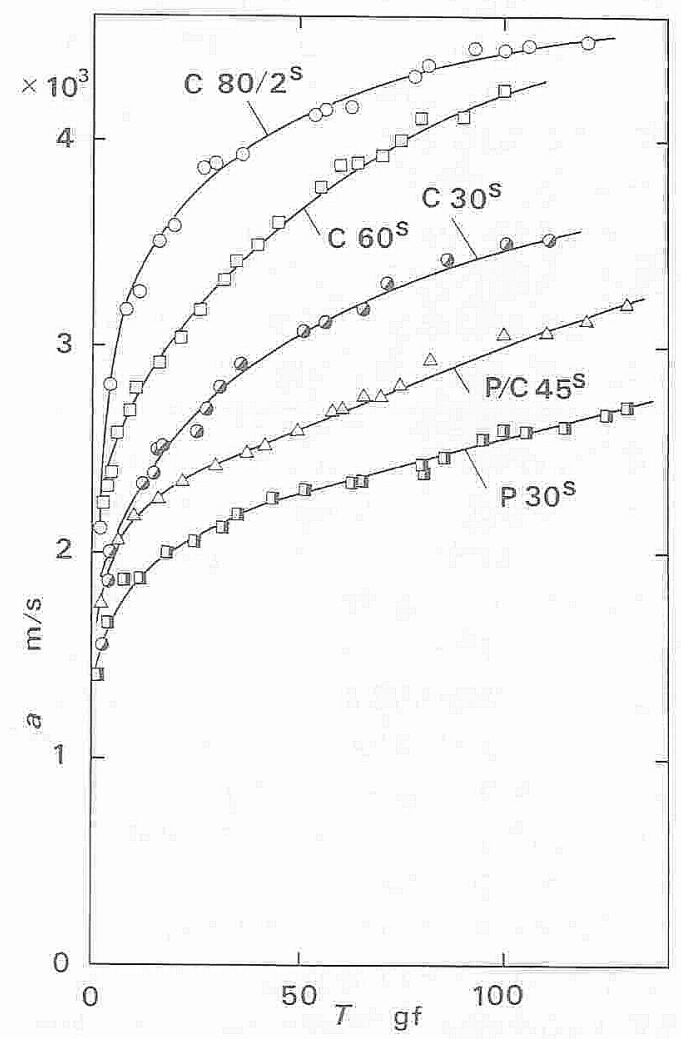

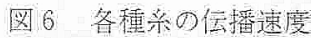


表 1 試験に使用した糸の特性

\begin{tabular}{|c|c|c|c|c|c|}
\hline 糸の種類 $\mathrm{Ne}$ & 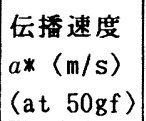 & $\begin{array}{l}\text { 伝播速度 } \\
a(\mathrm{~m} / \mathrm{s})\end{array}$ & $\begin{array}{c}\text { 平均強度 } \\
F(\mathrm{gf})\end{array}$ & $\begin{array}{l}\text { 最低強度 } \\
F \min (\mathrm{gf}) \\
\langle=\bar{F}-3 \quad \sigma)\end{array}$ & $\begin{array}{c}\text { 上限速度 } \\
F \min / a \rho \\
(\mathrm{m} / \mathrm{s})\end{array}$ \\
\hline cotton $20 \mathrm{~s}$ & 2800 & 1650 & 342.0 & 241.2 & 48.4 \\
\hline cotton & 3000 & 1670 & 232.8 & 156.0 & 46.5 \\
\hline cotton & 3110 & 1880 & 214.7 & 161.9 & 51.4 \\
\hline cotton & 3110 &.-- & 160.4 & 100.4 & -..- \\
\hline cotton & 3700 & 2030 & 136.8 & 99.9 & 49.2 \\
\hline cotton $80 / 2 \mathrm{~s}$ & 4150 & 2230 & 277.8 & 229.8 & 68.5 \\
\hline rayon & 2690 & 1870 & 312.0 & 200.0 & 53.2 \\
\hline polyester 30 s & 2300 & 1870 & 658.5 & 466.5 & 124.1 \\
\hline p.e./c. $45 \mathrm{~s}$ & 2590 & 1750 & 245.8 & 157.0 & 67.2 \\
\hline p.e./c. $84 / 2 \mathrm{~s}$ & 2690 & 1840 & 317.4 & 213.5 & 80.8 \\
\hline vinylon $30 \mathrm{~s}$ & 2330 & 1870 & 654.6 & 396.6 & 105.5 \\
\hline
\end{tabular}

c. :cotton, p.e. :polyester,

$a^{*}$ : 加振実験により測定した伝播速度（設定張力 $50 \mathrm{~g} \mathrm{f}$ )

$a$ : 張力ピーク值より計算した伝播速度 $\left(a=T_{p} /(\Delta v \rho)\right)$

$\rho:$ 系の線密度(実測值)

の場合には約 $2,600 \mathrm{~m} / \mathrm{s}$ で,さきに述べたよこ入れ 実験において張力波形から求めた値を大幅に上回っ ている.これらの理由については後述する.

さて次に，以上述べた伝播速度 $a$ と前述のよこ入 れ時の張力ピーク值 $T_{p}$ の関係を調べた。試験に用 いた系の種類と物性值を表 1 に示す。 $T_{p}$ の測定に 際しては， $P_{m}$ 並びに $P_{s}$ を適当に調整して,$\Delta v か ゙$ 一定となるようにしその平均値を求めた。 なお，試 験糸のなかには強度の低い系も含まれているので, 回転数は $N=300 \mathrm{rpm}$ とし, $\Delta v=49.2 \mathrm{~m} / \mathrm{s}$ とし た。 それでもC $40 \mathrm{~s}$ の場合には糸が切れて $T_{p}$ の測 定ではできなかった.

次に伝播速度 $a$ と張力ピーク值 $T_{p}$ の関係を調べ るに当たり, 張力が $50 \mathrm{gf}$ の場合の伝播速度をその 系の平均伝播速度 $a^{*}$ とおくことにする. 図 7 に, $a * \rho$ と $T_{p}$ の関係を示す. 罒より画者の相関は高い ことがわかるが, しかし $\Delta v a * \rho$ で計算される張力 に比べると，実測值は約30\%ほど小さくなっている. このような差が生じる理由としては，まず張力の関 数である伝播速度を，一定とみなして計算したこと による誤差の問題があるが，それ以上に，系の飛走 中のゆるみ，並びに伸長特性の非線形性の問題が影 響しているものと推定される．まず系の飛走中のゆ るみの影響であるが， $t_{p}$ 直後のよこ系姿勢をストロ ボスコープを用いて観察すると，糸は延びていると はいえエアガイドの中を波打ちながら飛走してお り，その波打ち具合からみて，全長に対し1ないし $2 \%$ ゆるみが生じ，このゆるみはサブノズル圧力 $P_{s}$ を増してもさほど減少することはない。こうし

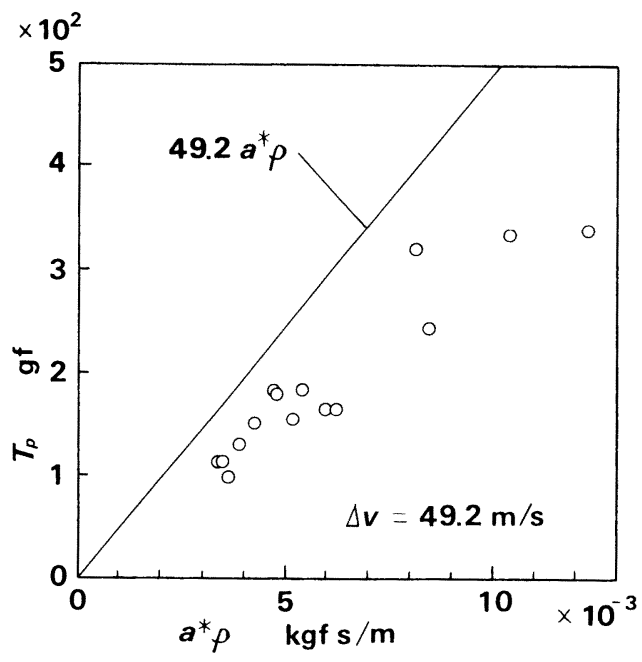

図 $7 a * \rho$ とピーク張力 $T_{p}$ の関係

たゆるみの存在は，その量がわずかであっても，系 の弾性率 $E$ を見掛け上大幅に減少させ，その結果， 伝播速度 $a$ さらには張力ピーク値 $T_{p}$ を大きく低下 させるものと推定できる.

次に伸長特性の非線形性であるが, 紡績系の場合, 元来かさ高であるため, 低ひずみの状態では, その 剛性はきわめて低く, 従って自由状態から急に張力 が変化する場合には，この剛性の低い領域は見掛け 上，上述のゆるみのようにふるまうと推定できる.

上記した $2 つ の$ 状態をここでは一括してゆるみと 呼ぶことにし，次に急制動を受けた際のこのゆるみ と張力伝播の関係式を導き，ゆるみの影響を検討す る. 


\section{5.ゆるみを伴う場合の張力変化}

\section{1 伝播速度}

$\varepsilon$ と $T$ の関係が下に凸の場合に，上流端の速度 がステップ的に減速した時には，その張力波頭にお いて張力は不連続となり，又，波頭より上流の張力 及び糸の速度は一定となって，波はいわゆる衝撃波 となることが知られている ${ }^{6}$.

ここで波頭前後の微小区間を検査面にとり，波頭 とともに移動する座標系において連続の方程式を適 用すると，次式が得られる。

$$
\rho_{1}\left(v_{1}-c\right)=\rho_{2}\left(v_{2}-c\right)
$$

ここで $v$ はいわゆる粒子速度で，添え字 $1 ， 2$ は波 頭の上流及び下流を示す，又，cは波頭の伝播速度 である。

次に同様な区問に対して運動量の法則を適用する と次式が得られる。

$$
\rho_{1}\left(v_{1}-c\right)^{2}-T_{1}=\rho_{2}\left(v_{2}-c\right)^{2}-T_{2} \cdots \cdot(4)
$$

(3)，(4)式より c を消去すると，

$$
T_{1}-T_{2}=\rho_{1} \rho_{2}\left(v_{2}-v_{1}\right)^{2} /\left(\rho_{2}-\rho_{1}\right)
$$

を得る．上式において $v_{1} ， v_{2}$ 及び $\rho_{2}$ はそれぞれ制 動の条件並びにゆるみの程度によりその値は既知で あり, 又, $T_{2}=0$ であるので, $T_{1}$ は $\rho_{1}$ の関数と して求まる.

ここで $T>0$ におけるひずみ $\varepsilon$ と張力 $T$ の関係 を，図 8 に示すように $T=E \varepsilon$ で近似すれば，ひ ずみ $\varepsilon$ と線密度 $\rho_{1}$ との関係は, $\varepsilon=0$ における線 密度を $\rho_{0}$ とすると, $\rho_{0}=(1+\varepsilon) \rho_{1}$ となるので,

$$
\rho_{1}=\rho_{0} /\left(1+T_{1} / E\right)
$$

又， $\rho_{2} を \rho_{0}$ とゆるみ率 $\alpha$ で表せば

$$
\rho_{2}=\rho_{0} /(1-\alpha)
$$

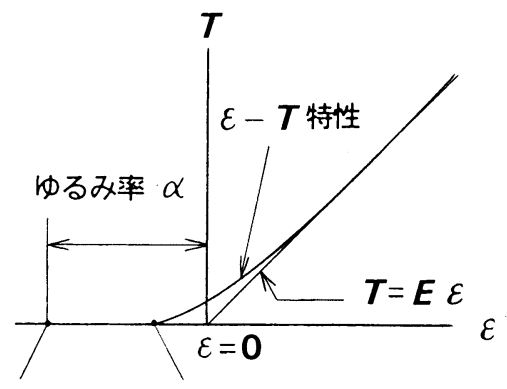

\section{飛走状態自由状態}

闵 8 ゆるみ率 $a$
となる. (6)，(7)式を(5)式に代入し $T_{2}=0$ とおいて 整理すると，

$$
T_{1}^{2}+E \alpha T_{1}-E \rho_{0}\left(v_{2}-v_{1}\right)^{2}=0 \cdots
$$

ここで $T_{1} \geqq 0$ より

$$
T_{1}=\left\{-\alpha E+\sqrt{\alpha^{2} E^{2}+4 E \rho_{0}\left(v_{2}-v_{1}\right)^{2}}\right\} / 2
$$

を得る。

又, 伝播速度 $c$ は(3)，(4)式から $\rho_{1}$ を消去し， $T_{2}$ $=0$ とおくと,

$$
c=\frac{T_{1}}{\rho_{2}\left(v_{2}-v_{1}\right)}+v_{2} \cdots \cdots \cdots \cdots \cdots \cdots \cdots \cdots \cdots(10)
$$

を得る，上式において，T1はすでに(9)式により求 まっており， $\rho_{2}$ は(7)式によって求まるので，cは 以下のようになる.

$$
c=\frac{-\alpha E+\sqrt{\alpha^{2} E^{2}+4 E \rho_{0}\left(v_{2}-v_{1}\right)^{2}}}{2 \rho_{0}\left(v_{2}-v_{1}\right) /(1-\alpha)}+v_{2}
$$

ここで $\alpha=0$ の場合すなわちゆるみが無い場合は伝 播速度 $c$ は $c=\sqrt{E / \rho_{0}}+v_{2}$ であり, 又, $\alpha=1$ の ときは, $c=v_{2}$ となる.

図 9 に，(9)及び(10)式より求めたゆるみ率 $\alpha$ と, $c$ 一 $v_{2}$ 並びに $T_{1}$ の関係を示す。なお四は $\mathrm{P} / \mathrm{C} 45 \mathrm{~s}$ の場 合で, $\sqrt{E / \rho}=2,600 \mathrm{~m} / \mathrm{s}$ として計算してある.曲 線の勾配はゆるみ率 $\alpha$ がゼロに近付くほど急となっ ており，わずかのゆるみが伝播速度を大きく減少さ せることがよくわかる。

さて次に，張力波が反射したのち上流に戻ってく る時の伝播速度を求める。この場合は(3)，(4)式に招 いて, $v_{1}=0, T_{2}=0, \rho_{2}=\rho_{0}$ とおき, $c$ につい

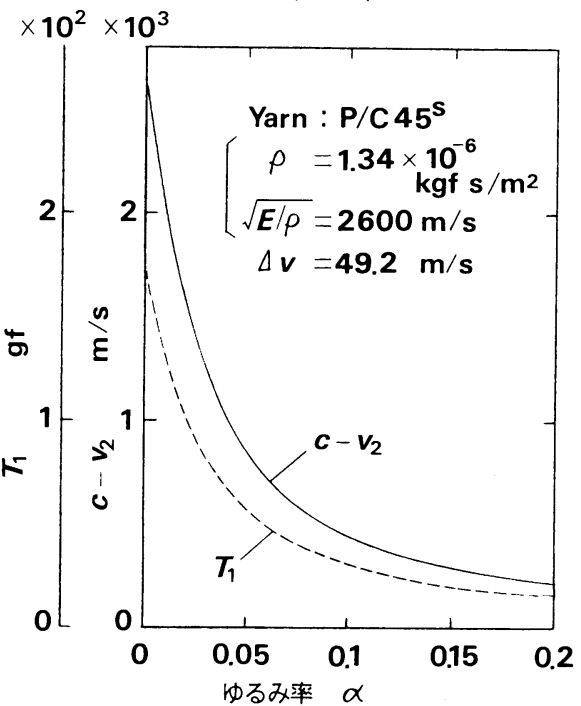

図 9 あみ率 $\alpha$ と, $T_{1}$ 及び $c-v_{2}$ の関係 
て解くと，次式を得る.

$$
c=-\left(1+T_{1} / E\right) \sqrt{E / \rho_{0}}
$$

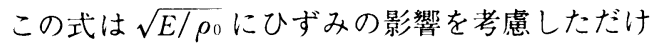
であり，当然ながらゆるみとは無関係である.

図 3 の説明の際に，パルス幅を用いて伝播速度を 求めた場合と，張力ピーク値を用いた場合とでは前 者の方がやや伝播速度が高くなることを述べたが, その理由は, 前者の場合は往復の伝播速度の平均値 を求めたことになるのに対し, 後者では下流端に達 するまでの片道の伝播速度を求めたことになるため である.

張力ピークから求めた伝播速度 $a$ は(11)式に対灾 し，四 9 より，伝播速度が $1,670 \mathrm{~m} / \mathrm{s}$ となるゆるみ 率は約 $2 \%$ と読取れ，これはゆるみ率の予想值とお おむね一致する。

以上，ゆるみと張力伝播の関係について述べてき た。ここで実務的な立場からは，よこ入れ実験を行 うことなく張力ピーク值あるいは伀播速度を知りた いという要求がある。ここで導いた関係式を用いて これを求めようとすると, 加振実験によって伝播速 度の測定を行う必要があり, 実用的とは言いがたい。 精度をある程度犠牲にしても，簡便に予測できる方 法があれば実用的な意義は大きいと考え，以下に示 す方法を試してみた.まず通常の引っ張り試験機(ひ ずみ速度 $1 \sim 2 \% / \mathrm{sec}$ 程度）によって $\varepsilon-T$ の関 係を求める。そしてその曲線から平均的な勾配を求 め, これを平均弾性率 $E_{s}$ とし，(2)式を用いて張力 を計算する，実際に各種の系について $\sqrt{E_{s} \rho}$ を求 め, 前述の張力ピーク値との関係をプロットした結 果を図10に示す.図より两者の相関はきわめて高く, 又， $\Delta v$ を代入して得られる張力は実測値によく一 致し， $E_{s}$ を用いる方法は充分実用となることがわ かる.この結果は周知のように弾性率がひずみ速度 に依存し，伝播速度算出に対して期せずしてゆるみ の影響とこのひずみ速度の影響の度合いが同程度で あったために生じたものであり，物理的な意味はそ しいが，実務上は有用な結果であると言える.

\section{2 噴射条件の影響}

前節まではいわば正常なゆるみ状態の場合の張力 伝播の特徵について述べてきた。よこ入れ条件次第 では，ゆるみが極端に多くなったり，又，特定の位 置に分布する場合があり，このような場合張力に対 するゆるみの影響はきわめて複雑となる。そこで次 に，高よこ人れ率のもとで，ゆるみと関連の深いメ イン及びサブノズルの供給庄力を大きく変化させ,

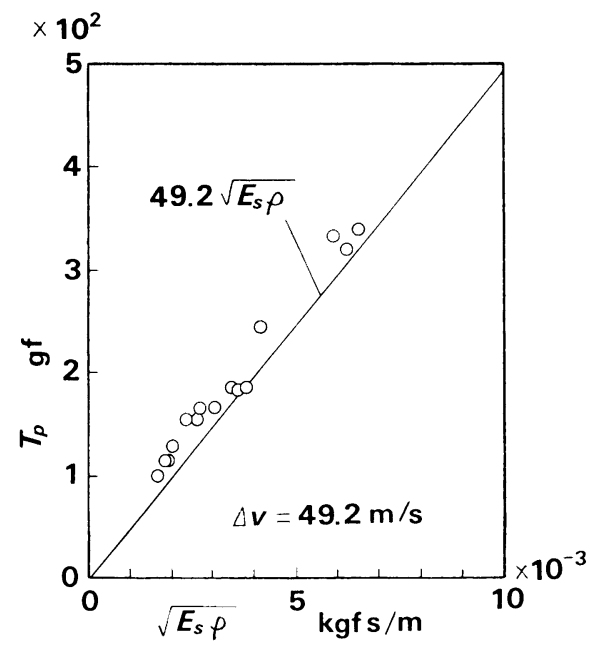

図10 $\sqrt{E_{s} \rho}$ と $T_{p}$ の関係

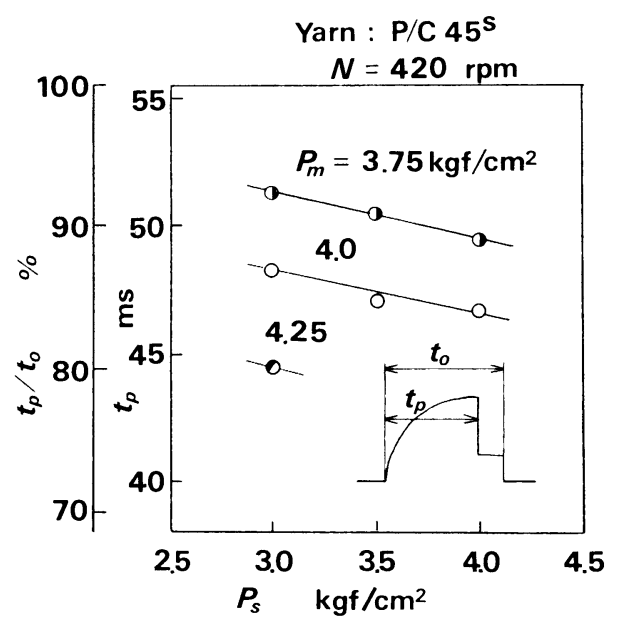

四11 $P_{s}$ と $t_{p}$ の関係

ゆるみと張力波形との関連性を検討する。

図 11 に，織機回転数を $420 \mathrm{rpm}$ (よこ入れ率 $1,537 \mathrm{~m} / \mathrm{min}$ ) に設定し，メインノズル及びサブノ ズルの供給圧力 $P_{m}, P_{s}$ を変え $t_{p}$ を測定した結果を 示す。この回転数は，後述するように試験に用いた $T / C 45 \mathrm{~s}$ 糸の場合に，糸切れが頻発することなく 試験可能なほほ上限の回転数である。なお四中のプ ロットは100回のよこ入れの平均值を示している.

又, 図12に系先端の平均速度 $V$ を示す。四11より tp $t_{p}$ の強い影響を受け，一方，Ps についてはさ ほど影響を受けないことがわかる。しかし祖12に示 すように，Ps が低くなれば，よこ入れ後半で系先 端速度が低下し，ゆるみは増加する。ここで，この ゆるみはサブノズルの噴射条件からみて図13に示す ように系の中央部に集中する。すなわち図 2 に示し たようにサブノズルはリレー噴射され，系先端に集 中して気流が吹付けられていることから，系先端の 


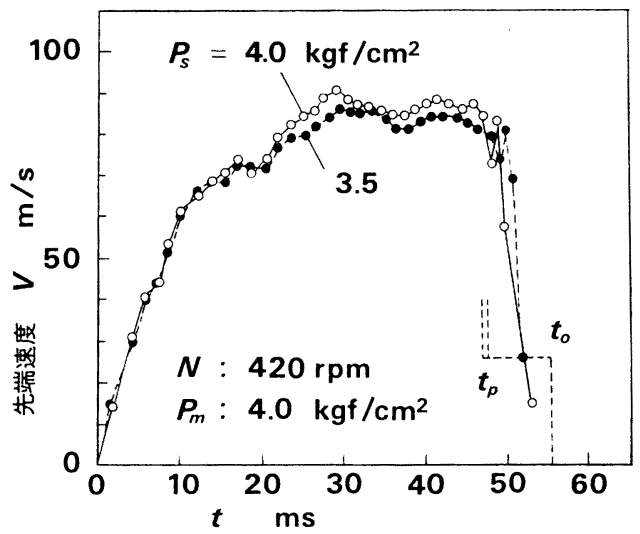

図12 系の先端速度

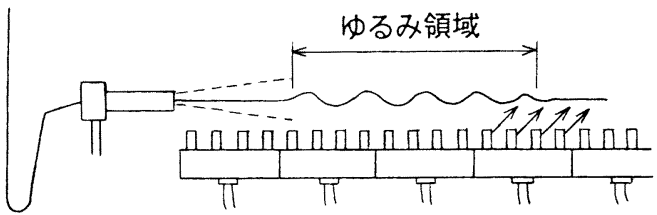

図13ゆるみ領域

姿勢は常に延びた状態に保たれる，又，よこ系の上 流部もメインノズルの空気力によりやはり延びた状 態に保たれるので，従ってP $P_{s}$ が低いときに生ずる ゆるみは，図13に示すようにサブノズルの空気力が 直接作用しない中央部に集中して分布することにな る.

図14は, $P_{m}, P_{s}$ を変えたときの張力波形例を示す. $P_{s}$ が高い(3)，(6)では， $t_{p}$ と $t_{0}$ の際に独立に張力上 昇が生じているが, $P_{s}$ が低くなると $t_{p}$ の際のパル ス波は $\mathrm{a}_{1}, \mathrm{a}_{2}$ の 2 つの山に分離し， $P_{m}$ が增加する ほどその時間間隔は広がっていく。このような波形 の分離は糸中央に多量のゆるみがある場合の特徽的 な現象で，その発生は以下の機構によるものと考え られる.すなわち自由噴射が終了すると上流端近く では系は延びているので上流端から張力波が高速で 下流に向って伝播していくが，波頭がゆるみの多い
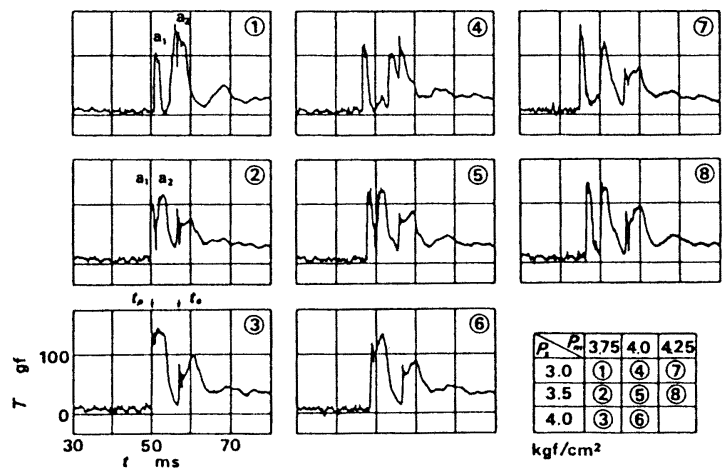

図14 張力波形の変化
領域にさしかかると，波の速度は急速に低下し，同 時に波の一部は反射して上流に向かって引返してく る.このときの波形が a 1 に相当する．糸の先端は この期間も移動を続けて㧍り，この先端部が次に制 動を受けた段階で $\mathrm{a}_{2}$ で示す張力波が発生する。こ のように伝播の特性からいって $t_{p}$ 直後に生ずる張 力波のピーク値は, 上流端の正常な領域のゆるみ率 と速度差 $\Delta v$ に依存し, 系中央のゆるみ状態には無 関係である，上流端はさきに述べたようにメインノ ズルの空気力の影響を受けて延びており，従って $t_{p}$ 直後に生ずる張力波形のかたちから，延びている領 域の範囲を推定することが可能である。またこのよ うに張力波形が，2つの山に分離する場合には，(1) に示すようにあとの山の一部が, その発生タイミン グによっては $t_{0}$ の際に生ずるピークに重畳し, $t$ のピーク張力が $t_{p}$ 時のそれよりも高くなることが ある。

\section{6. 糸切れからみたよこ入れ率の上限}

織機を高速化した場合，よこ系速度は高くなって そのぶん張力も増し，系切れによるミスの発生頻度 は高くなる，通常，工場において効率よく布を織る ためには，よこ入れミス頻度は10万ピックに 1 回以 下が要求され，ここでは，各種の糸について，こう した要求を満たしてよこ入れできるよこ入れ率の上 限を求めることにする，最初によこ入れ率の上限を 求めるに当たり，よこ入れの上限を与える速度差 $\Delta v$ を求める.

紡績系の場合, 破断強度は通常一定ではなく, か なり大きなばらつきを持っている。ごくまれに発生 する系切れを考える場合は, 強度分布の裾にあたる 分布の形が重要な意味を持ち, これに何らかの方法 で求めておく必要がある. 図15はヤーンストレング ステスター（Zellweger Uster 社製）を用いて行っ た強度試験の一例であるが，分布の形をここで仮に 正規分布とみなすならば，裾の部分の出現確率は， 図16のようになって, 出現確率が 1 回以下 $/ 10$ 万回 となるのは $\bar{F}-5 \sigma$ となる. ただし $\bar{F}$ は平均強度, $\sigma$ は標準偏差である. しかしながら現実の問題とし て，強度分布の裾にあたる部分は系の管理状態に関 係し，高速で織機を連転する際には充分な系質の管 理がなされるはずである。そこで充分な管理を期待 し，やや楽観的ではあるが 1 回以下 $/ 10$ 万回の出現 確率となる強度 $F \min を, F \min =\bar{F}-3 \sigma$ で見積 ることにする。このように $F \min$ を決めるならば, $\mathrm{P} / \mathrm{C} 45 \mathrm{~s}$ の場合，F $F$ in は $157.0 \mathrm{gf}$ となる，表 1 に は, 各種の系についての $F \min$ が示してある. $F$ 


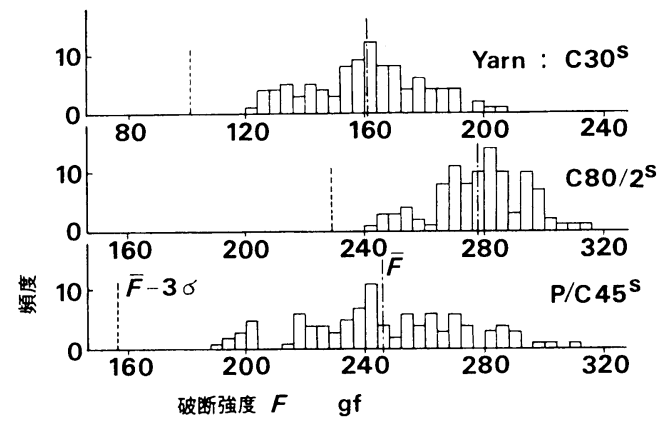

図15 破断強度分布 $(\mathrm{n}=100$ 回 $)$

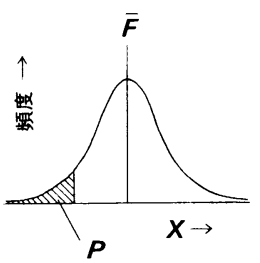

$$
\begin{aligned}
& P(X<\bar{F}-3 \sigma)=1.35 \times 10^{-3} \\
& P(X<\bar{F}-4 \sigma)=3.17 \times 10^{-5} \\
& P(X<\bar{F}-5 \sigma)=2.87 \times 10^{-7}
\end{aligned}
$$

図16 出現確率（正規分布と仮定した場合）

$\min$ が決まれば先に示した $T_{p}$ の結果を用いて $F$ $\min$ に対応する速度差 $\Delta v$ が求まり， P/C $45 \mathrm{~s}$ の場 合には， $F \min$ に対応する速度差として $67.2 \mathrm{~m} / \mathrm{s}$ が得られる. 又, 表 1 をみると, 同じ綿系であって も番手や双系，単系の違いにより速度差 $\Delta v$ の上限 値がばらついているが，一般に糸の種類によりその 用途を考えて原料の質や系構造が選択されるという 紡績糸の実情を考えれば，むしろこの結果は当然と 言える。ともあれ綿単系の場合には， $50 \mathrm{~m} / \mathrm{s}$ あた りが $\Delta v$ の上限の一応の目安と考えられ，ビニロン 系やポリエステル系などの化合繊系では， $\Delta v$ が $100 \mathrm{~m} / \mathrm{s}$ を超えるような高速製織が可能であること がわかる.

次によこ入れ率の上限を求める. エアジェットル 一ムのよこ入れ時間は, 系貯留装置の如何にかかわ らず通常クランク角度で $140^{\circ}$ 程度に設定される. 織幅や回転数が变わってもこの角度が保たれるとす れば，よこ系の平均速度（織幅/よこ入れ時間）と よこ入れ率（織機回転数 $\times$ 織幅）とは比例するこ とになる。しかし， $\Delta v$ については眝留装置や噴射 条件に依存する，図17は，本実験に用いたエアプー ル装置を貯留装置として使用し，織幅及び回転数を 変えて，系速を測定した結果を示す．条件によって ややばらつきはあるが， $t_{p}$ での速度差 $\Delta v に$ にいて もよこ入れ率に比例するとみてよい，又，糸の種類 が変わっても, 図17の斜線の範囲はほほ一致する. 従って，速度差 $\Delta v$ が求まれば，眓よりよこ入れ率 が求まる，P/C $45 \mathrm{~s}$ の場合は，よこ入れ率の上限は 抢よそ $1,600 \mathrm{~m} / \mathrm{min}$ となり，綿単系のそれはおよ

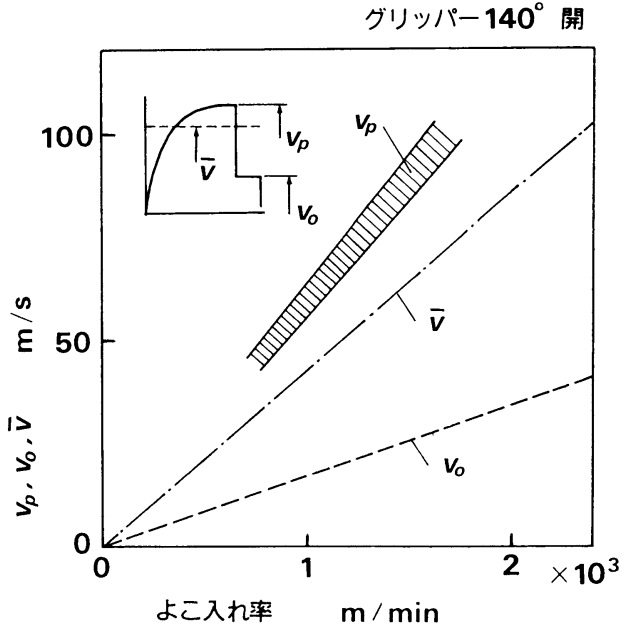

図17 よこ入れ率と糸速の関係

そ $1,200 \mathrm{~m} / \mathrm{s}$ である.

\section{7. まとめ}

エアジェットルームに扔いて，よこ系として紡績 系を用いた際のよこ入れ終了時に発生する張力上昇 に関して実験により調べ，次のような結果を得た。

(1)エアプール方式において，局部的なゆるみを伴 うことなく糸が正常に飛走する場合には，自由噴射 終了時 $t_{p}$ 及びグリッパ閉時 $t_{0}$ の 2 度にわたって張 力がパルス状に急上昇する。

(2) $t_{p}$ 時に生ずる張力波の伝播速度は，加振実験 により求めた值に比べ $30 \%$ ほど低い，その原因とし ては，系が正常に飛走する場合でも，わずかではあ るがゆるみを伴うためと考えられる。

(3)ゆるみ率と伝播速度の関係式を導き，ゆるみの 張力上昇に及ぼす影響を明らかにするとともに、リ レー噴射の特徴である糸中央に局部的なゆるみがあ る場合について，張力波形の発生状況を実験により 明らかにした。

(4)よこ入れ時間がクランク角度で $140^{\circ}$ の場合, 系切れ率からみたよこ入れ率の上限は，P/C $45 \mathrm{~s}$ で はおよそ $1,600 \mathrm{~m} / \mathrm{min}$, 綿単糸ではおよそ 1,200 $\mathrm{m} / \mathrm{min}$ と予想された.

\section{参考文献}

1) W. J. Lyons ; Inpact Phenomena in Textiles, 1963, M. I. T. Press

2) N. Cristescu; 衝慗塑性学, 1967, 黑崎永治訳, コロナ社

3）団洞爺；緎維機械学会誌，32, No. 10, (1979)，33

4) 千布正雄；繊維機械学会論文集，23，No. 1/2, (1970), 16

5）伊藤平八郎；瀻維と工業， 3， No. 10， (1970), 709

6) J. C. Smith, J. M. Blandford \& K. M. Towne, Text. Res. J., 32, (1962), pp 67-76 